\title{
Treatment of Unruptured Intracranial Aneurysms in Autosomal Dominant Polycystic Kidney Disease: Primum Non Nocere
}

A utosomal dominant polycystic kidney disease (ADPKD) belongs to the most common genetic disorders, with approximately 12.5 million individuals involved worldwide. The disease is a well-known risk factor for intracranial aneurysms (IAs). ${ }^{1}$ The rupture of an IA is associated with a high risk of serious complications or death, ${ }^{2,3}$ yet universal screening for IAs in ADPKD remains controversial. It is mainly due to the potential risk connected to pre-emptive treatment of IAs and the cost of screening. ${ }^{4}$

Indeed, according to the study of Rozenfeld et al, ${ }^{5}$ patients with ADPKD have an increased risk for complications during treatment of unruptured IAs compared with the general population. The difference in the complication rate between patients with and without ADPKD is especially striking in cases of endovascular coiling. Most probably, it is attributable to ADPKD-specific, ciliopathy-related, dysfunction of the vascular wall, which is nota bene the main pathomechanism of vascular manifestations of ADPKD, including aneurysm formation, hypertension, and others. $^{6}$

However, quitting or reducing screening for IAs is not a solution because screening potentially leads to the protection of life or health of numerous relatively young people; the average age at IA rupture in ADPKD is approximately 40 years, and the risk of death or persistent disability after the rupture is estimated to be almost $50 \% .^{2,7}$ On the other hand, most IAs detected by screening are small; thus, the risk for their rupture is low. ${ }^{8}$ Additionally, the risk for progression of IAs in ADPKD is quite low and comparable with that in the general population. ${ }^{9,10}$ Therefore, the key issue is to make decisions on treatment only in patients with substantial risk for IA rupture; in most patients with ADPKD and IA, watchful surveillance is required rather than treatment.

The problem is that the rupture-risk assessment is still challenging. Current treatment guidelines are similar in patients with and without ADPKD. ${ }^{11}$ However, due to the differences in pathogenesis and clinical characteristics between IAs in ADPKD and the general population, IAs in ADPKD may be considered a distinct clinical entity. Therefore, treatment rules applicable for the general population may not be fully appropriate in ADPKD. There is effort to improve the assessment of risk for IA progression and rupture with clinical and radiographic features ${ }^{12}$ and a molecular biology approach. ${ }^{13,14}$ However, these new risk factors have to be tested in the ADPKD population to verify their utility in this particular group.

Until now, data on risk factors for IA rupture in ADPKD are limited. According to Ring and Spiegelhalter, ${ }^{15}$ IA rupture tends to cluster in ADPKD families, which strongly suggests a role of genetic factors, which, however, still need to be identified. Among clinical features, headache was recently proposed as a factor predictive for IA rupture. ${ }^{16}$ Most surprising, headache was previously not even considered as an indication for screening for IAs in ADPKD. ${ }^{17}$

In summary, considering the relatively low risk for rupture in most IAs in patients with ADPKD and the increased risk of complications connected to their treatment, the treatment decisions must always be cautious and individualized. Additionally, effort should be made to improve the assessment of the IA rupture risk, including searching for ADPKD-specific risk factors.

\section{REFERENCES}

1. Chapman AB, Devuyst O, Eckardt KU, et al; Conference Participants. Autosomal-dominant polycystic kidney disease (ADPKD): executive summary from a Kidney Disease: Improving Global Outcomes (KDIGO) Controversies Conference. Kidney Int 2015;88:17-27 CrossRef Medline

2. Gieteling EW, Rinkel GJ. Characteristics of intracranial aneurysms and subarachnoid haemorrhage in patients with polycystic kidney disease. J Neurol 2003;250:418-23 CrossRef Medline

3. Zuka M, Onoe T, Kawano M, et al. Sudden death of a young male with previously undiagnosed autosomal dominant polycystic kidney disease (ADPKD). Leg Med (Tokyo) 2011;13:35-38 CrossRef Medline

4. Klein JP. On the role of screening for intracranial aneurysms in autosomal dominant polycystic kidney disease. AJNR Am J Neuroradiol 2013;34:1560-61 CrossRef Medline

5. Rozenfeld MN, Ansari SA, Mohan P, et al. Autosomal dominant polycystic kidney disease and intracranial aneurysms: is there an increased risk of treatment? AJNR Am J Neuroradiol 2015 Sep 3. [Epub ahead of print] CrossRef Medline

6. Rahbari-Oskoui F, Williams O, Chapman A. Mechanisms and management of hypertension in autosomal dominant polycystic kidney disease. Nephrol Dial Transplant 2014;29:2194-201 CrossRef Medline

7. Chauveau D, Pirson Y, Verellen-Dumoulin C, et al. Intracranial an- 
eurysms in autosomal dominant polycystic kidney disease. Kidney Int 1994;45:1140-46 CrossRef Medline

8. Xu HW, Yu SQ, Mei CL, et al. Screening for intracranial aneurysm in 355 patients with autosomal-dominant polycystic kidney disease. Stroke 2011;42:204-06 CrossRef Medline

9. Irazabal MV, Huston J 3rd, Kubly V, et al. Extended follow-up of unruptured intracranial aneurysms detected by presymptomatic screening in patients with autosomal dominant polycystic kidney disease. Clin J Am Soc Nephrol 2011;6:1274-85 CrossRef Medline

10. Jiang T, Wang P, Qian Y, et al. A follow-up study of autosomal dominant polycystic kidney disease with intracranial aneurysms using 3.0 $\mathrm{T}$ three-dimensional time-of-flight magnetic resonance angiography. Eur J Radiol 2013;82:1840-45 CrossRef Medline

11. Ars E, Bernis C, Fraga G, et al; Spanish Working Group on Inherited Kidney Disease. Spanish guidelines for the management of autosomal dominant polycystic kidney disease. Nephrol Dial Transplant 2014;29 (suppl 4):iv95-105 CrossRef Medline

12. Tominari S, Morita A, Ishibashi T, et al; Unruptured Cerebral Aneurysm Study Japan Investigators. Prediction model for 3-year rupture risk of unruptured cerebral aneurysms in Japanese patients. Ann Neurol 2015;77:1050-59 CrossRef Medline
13. Zhang LT, Wei FJ, Zhao Y, et al. Intracranial aneurysm risk factor genes: relationship with intracranial aneurysm risk in a Chinese Han population. Genet Mol Res 2015;14:6865-78 CrossRef Medline

14. Xu J, Ma F, Yan W, et al. Identification of the soluble form of tyrosine kinase receptor $\mathrm{Axl}$ as a potential biomarker for intracranial aneurysm rupture. BMC Neurol 2015;15:23 CrossRef Medline

15. Ring $T$, Spiegelhalter D. Risk of intracranial aneurysm bleeding in autosomal-dominant polycystic kidney disease. Kidney Int 2007;72: 1400-02 CrossRef Medline

16. Niemczyk M, Niemczyk S, Bujko M, et al. Headache as a manifestation of intracranial aneurysm in autosomal dominant polycystic kidney disease. Neurol Neurochir Pol 2015;49:126-28 CrossRef Medline

17. Bajwa $\mathrm{ZH}$, Sial KA, Malik AB, et al. Pain patterns in patients with polycystic kidney disease. Kidney Int 2004;66:1561-69 CrossRef Medline

M. Niemczyk

Department of Immunology, Transplant Medicine and Internal Diseases Medical University of Warsaw Warsaw, Poland

http://dx.doi.org/10.3174/ajnr.A4538 